\title{
Interactive Application Development Policy Object 3D Virtual Tour History Pacitan District based Multimedia
}

\author{
Muga Linggar Famukhit \\ Informatics Faculty, University of Surakarta \\ Surakarta, Indonesia \\ Lies Yulianto \\ Pacitan, Indonesia
}

\author{
Maryono \\ History Educational, High School Science Teacher and Education \\ Pacitan, Indonesia
}

Bambang Eka Purnama

Informatics Faculty, University of Surakarta

Surakarta, Indonesia

\begin{abstract}
Pacitan has a wide range of tourism activity. One of the tourism district is Pacitan historical attractions. These objects have a history tour of the educational values, history and culture, which must be maintained and preserved as one tourism asset Kabupeten Pacitan. But the history of the current tour the rarely visited and some of the students also do not understand the history of each of these historical attractions. Hence made a information media of 3D virtual interactive applications Pacitan tour history in the form of interactive CD applications. The purpose of the creation of interactive applications is to introduce Pacitan history tours to students and the community. Creating interactive information media that can provide an overview of the history of the existing tourist sites in Pacitan The benefits of this research is the students and the public will get to know the history of historical attractions Pacitan. As a media introduction of historical attractions and as a medium of information to preserve the historical sights. Band is used in the manufacturing methods Applications 3D Virtual Interactive Attractions: History-Based Multimedia Pacitan authors used the method library, observation and interviews. Design using 3ds Max 2010, Adobe Director 11.5, Adobe Photoshop CS3 and Corel Draw. The results of this research is the creation of media interakif information that can provide knowledge about the history of Pacitan.
\end{abstract}

Keywords-Interactive 3D Virtual Application Development Object-Based Tourism Pacitan History Multimedia

\section{INTRODUCTION}

Pacitan has a wide range of tourism. One of the objects Pacitan tourism is travel history. Travel history Pacitan consists of various monuments and museums. Historical sights are Jend Sudirman Monument, Monument Tumpak Rinjing Theater and Museum Buwono Keling. These objects would have historical value of education, history and culture, which should be maintained and preserved as one of the tourism assets Pacitan. (Qomaruddin Sartono, 2006).

With the development of a wide range of attractions and entertainment in Pacitan, historical tourism is increasingly less attractive and rarely visited by tourists and the community, building one of the largest and grandest monuments Pacitan received little response from the visitors. The existence of such monuments to lose competitiveness with visitors coastal resorts and shopping districts in Pacitan, it will certainly make the historical sights unnoticed by the public and students. (Mahendra Rizki, 2008). Society and current students are also many who do not understand the history of the objects that exist in the historical Pacitan. (Quesioner).

In the world of education and tourism one way to introduce a tourism object, can be presented by using a medium of information. Media information can be developed is digital information media, namely by using computer technology. Because the digital information media, information can be delivered more user friendly and very enjoyable to use. (Novitasari, 2011).

There are various types of media digital information developed at this time, one of which is a multimedia computer technology. Multimedia computer technology to make the delivery of information can be conveyed with more interactive because the reach of human senses. This is because multimedia is made up of various elements of the text, art, sound, animation and video. (Vaughan, 2004).

Virtual Reality 3D is part of the multimedia objects. Virtual reality is a 3D image in a computer or in another world (maya) that can make people feel in the real world and can perform the operation and control of real-life systems. (Daren L.I, 2009).

\section{A. Problem Formulation}

a)Starting lack of interest in the community to find out more details about the museum and the history

b) How to make technological innovations that can be used as a media introduction Pacitan historical sights?

\section{B. Limitation Problem}

a) Object of research on the history of the monument tour General Sudirman, Monuments and Museum Theater Tumpak Rinjing Keling lane.

b) Computer-based desktop 


\section{The Purpose}

a) Creating Applications Interactive $3 D$ Virtual Tour History Pacitan Object-Based Multimedia band is used as a means of introduction to historical sights to students and the public.

b) Creating interactive information medium that can provide an overview of historical tourist sites Pacitan.

\section{BENEFITS}

a) As a media introduction of the history of tourism objects that exist in Pacitan.

b) As a medium for preserving historical information to students and the public.

\section{TOURISM}

According to Richart Shite (2000), Tourism is travel that people do for a while, which was held from from one place to another, melinggalkan its original position, with a plan and with the intention not to seek or make a living in the places visited, but simply -eyes to enjoy pertamasyaan activities and recreation to meet the diverse activities.

\section{A. History}

According Suhartono W. Pranoto (2009) history is a science that studies and investigates the events of the past, which include science, investigation and recording. In other words, human history kelampauan include activities in the community and is unique.

Meanwhile, according to Kartikadarma Ethics (2010) is literally syajarah birth history, in the narrow sense that pedigree, origin or history.

In line with the development of knowledge, understanding sejarahpun development. Based on the shape and nature of history is divided into two terms, namely:

\section{c) History As Events}

Historical events are events that happened in the past. In other words, the history of the event is the historical process in its actuality (History as past actuality or histoire-réalité). This means the event history is objective, because the event was purely as happened.

\section{d) History As the Story}

History is the story as told in writing history (History as written / Histoire Recite) based on the results of the research. In other words, the history of the story is the reconstruction of historical events based on historical fact. The event is especially important events concerning human life in general.

\section{B. Multimedia}

Multimedia is a combination of computer and video (Rosch, 1996) or Multimedia is generally a combination of three elements, namely the sound image and text (McMormic, 1996) or multimedia is a combination of at least two media input or output image (Turban et al, 2002) or Multimedia is a tool that can create a dynamic and interactive presentations that combine text, graphics, animation, audio and video and image video (Robin and Linda, 2001).
Meanwhile, according to Ariyus Dony (2009) Multimedia derived from two words, namely multi and media. Multi means many regular and defined media tools to communicate or make something, equipment, tools introduction, a form of communication such as newspapers, magazines, or television. When linked with computer processing, multimedia is considered as a tool which displays the text, images, graphics, sound, music, and so on. Multimedia systems in question here is a technology that combines a media source such as text, graphics, sound, animation, video, etc., delivered and controlled by the interactive computer system.

\section{Virtual Reality}

Virtual Reality (VR) is a development of the artificial (man-made) based computer technology that can be controlled by the user using the mouse (USA, Ranang and Agustin, 2007:1). VR interactive key points lies in the hands of the user controls the enjoyment of photos by moving the mouse or by pressing the keyboard. In another sense Virtual Reality technology is also often referred to as Quick Time Virtual Reality (QTVR) is a mode to view an image as if we were in the picture and can see all the way (Vaughan, 2006:451).

\section{Application Programs $3 d$ Studio Max}

According to Thabani Suyanto 3D Studio Max is a software visualization (modeling and animation) threedimensional popular and versatile. Since its first release, 3D Studio Max to be a leader pembanggunan application of threedimensional animation. Since the fourth version, Discreet, 3D Studio Max producers, seeking to expand its area of function that can be used to create animations for the web or movies. The latest version, version 5, has led to the expansion of the function. This is indicated by the development of the polymodeling, mapping and some revisions to the tool for animation. But of features, the most interesting features of 3D Studio Max is a reactor. Reactor is integrated with inface of 3D max and provides tools to create simulations. 3D Studio Max is often used to create models of houses or furniture. In addition, many are used in digital art or game development. (Mr. Suryanto Thabani, MM, 2004).

\section{E. Application Program Adobe Director}

Adobe Director is a software created by Macromedia and is now part of Adobe Systems. which allows users to build software in a movie metaphor, which enable users to become a film director. Originally designed to create animations, adding a powerful scripting language called Lingo made a popular choice to make CD-ROMs and standalone kiosks and web content using Adobe Shockwave. Adobe Director multimedia projects supporting both 2D and 3D. Adobe Director software is not all can. Adobe Director is software to assemble multimedia components and graphics. (Hendi Hendratman, St, 2008).

\section{F. Program Application Adobe Photoshop}

Photoshop software is used to modify images or photos in a professional manner both involve a modification of a simple object or a rumut though. Photoshop is a software that allows you to reject the bitmap-based picture, which has a highquality tool. Completeness of existing features in Photoshop is what makes this software much akhrnya band is used by 
professional graphic designers. And perhaps to this day there is still no other graphic design software to match the completeness bias features in Photoshop. (Boediman, 2005)

\section{G. Application Program Adobe Flash}

Adobe Flash CS3 is an application program professional standard authoring tool released by Adobe international company that is used to create vector and bitmap animation was amazing for the purposes of web site development, interactive and dynamic. Also this application can also be used to load animated logos, movie, game, making navigation on websites, banners, animated buttons, menus, interactive form fields, e-cards, screen server, and web site creation or production applications other web. (Suciadi, 2003: 3).

\section{H. Program Corel Draw}

Corel Draw program is a program used for applications illusion images and text quickly and easily with maximum results and satisfying. Corel Draw is also used to create vector-based graphics that the user can easily create a hightech graphic design such as logos, caricatures, posters, brochures, calendars, labels, stickers and other free images. (Erhans, 2005).

\section{Studies Library}

The study was made by Latitude Yanuar Bawono Sari, Aji Widhi Wibisono and Fatra Firdaus S.Syaiful, Gunadarma University, the work was entitled "Making the Virtual Museum of Culture and Art", saying that the public interest in the preservation of cultural Indonesia has decreased, especially the younger generation, it is based on data from the department of Culture and Tourism in the year 2005-2009. Decline in public interest in the culture, because of the lack of communication media used interestingly. In that study, one solution that can be used to introduce the culture to the younger generation through a $3 \mathrm{D}$ virtual world that resembles a game on the computer.

Research has also been done by Heri Susanta and Gondang Riyadi in 2008, the work was entitled "3-D Model Town area of Simpang Lima for Exploration in Virtual City". Heri Susanta in the work was to provide information to the public about tourism in the virtual 3-dimensional shape. Virtual 3dimensional model was chosen because it can increase public understanding of the tourist resorts. Virtual 3-D can also band is used for promoting the effective and efficient, because obek-object to represent the state as the original. Same thing in this study is to provide information to students and the public about the history of tourism objects in a virtual threedimensional shape.

Based on the study conducted by Latitude Yanuar Bawono Sari and Heri Susanta, so in this study the authors want to make media information such as Application Object Interactive 3D Virtual Tour History-Based Multimedia
Pacitan. Applications in the form of Virtual 3D to represent the historical sights such as the original state, so expect the students and the community more aware of the objects of historical Pacitan.

\section{Historical Photo Collection OF TRAVEL LOCATION}
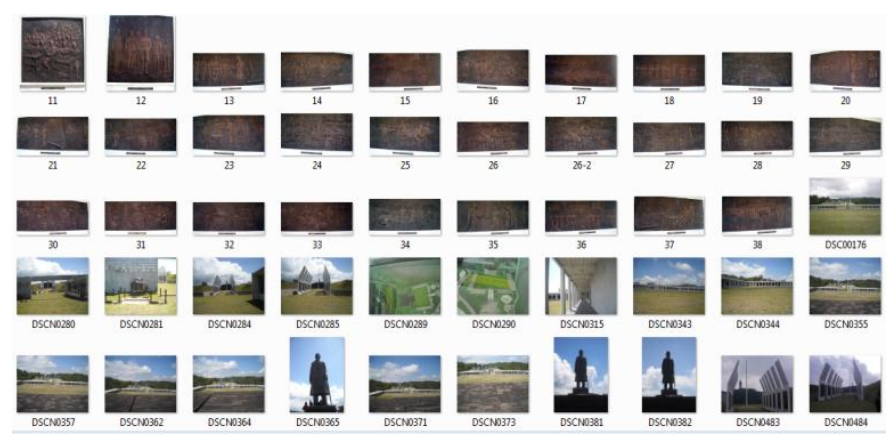

Fig. 3.1. Photo Location History Tours

A. Making History Tours Sitemap

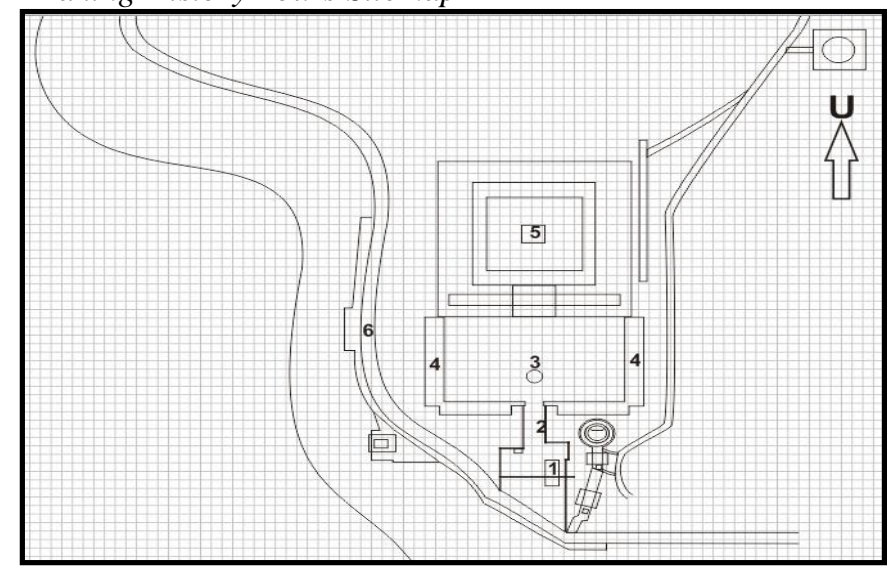

Fig.3.2. Making History Tours Sitemap

B. Import Data Plan Into 3d Max

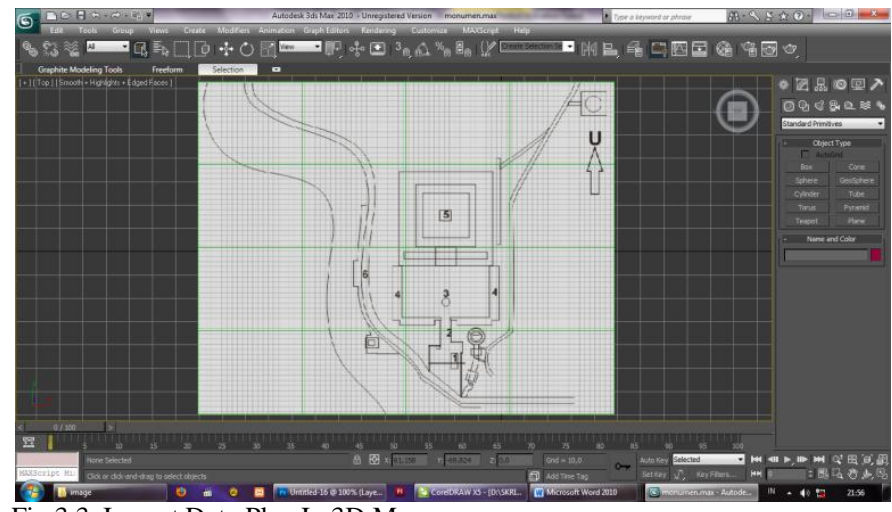

Fig.3.3. Import Data Plan In 3D Max 
C. Building Making History Tours

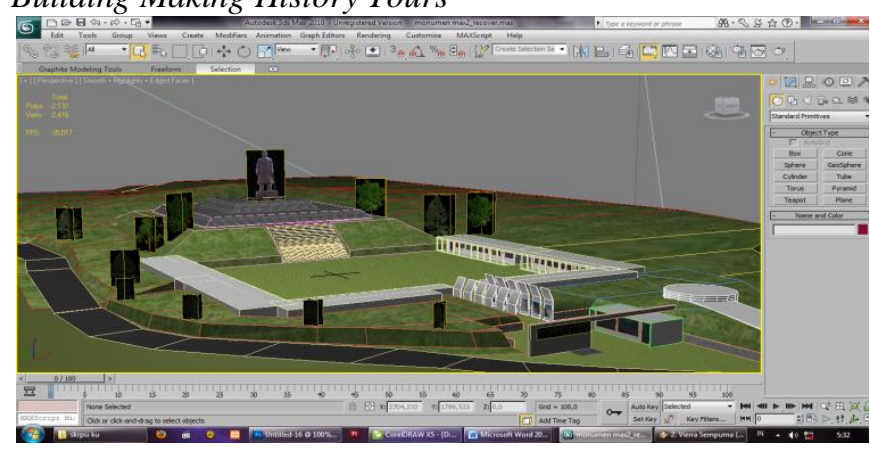

Fig.3.4. Import Data Plan In 3D Max

D. Export 3d Max File Into A Format W3d

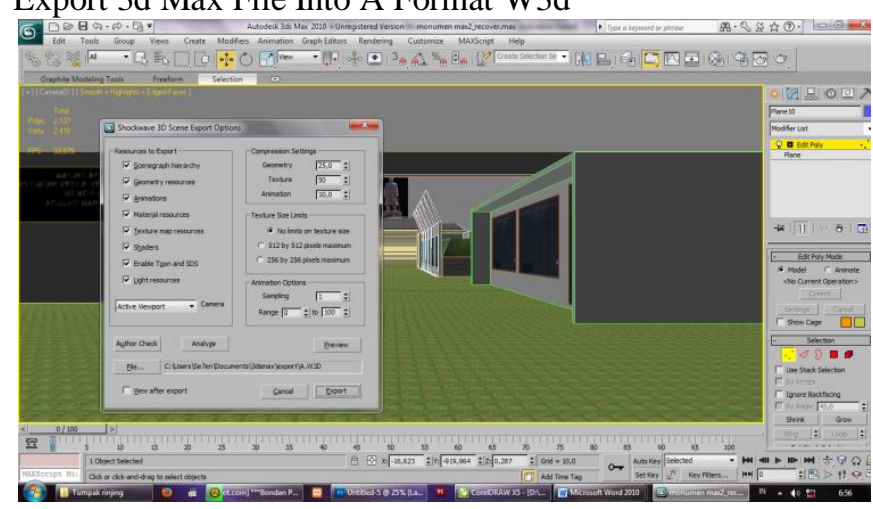

Fig.3.5. Export 3D files into the format "W3D"

E. Pengabungan Materials, Components And Export File In Shape Exe

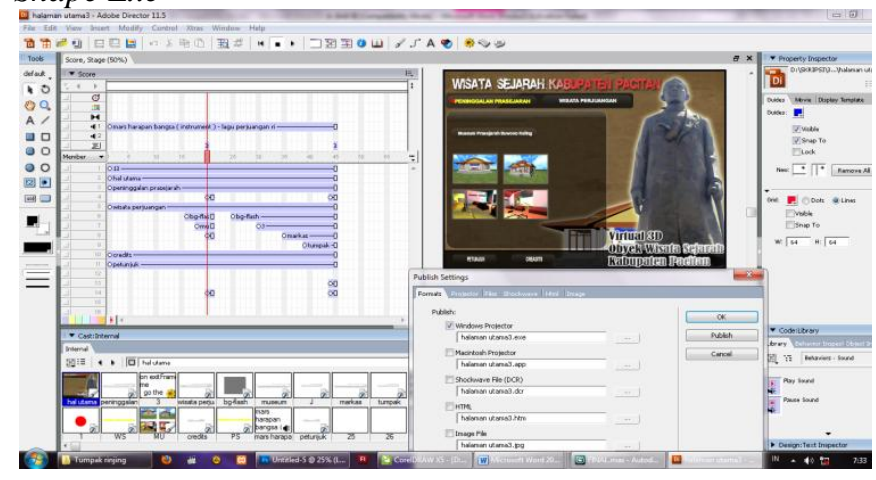

Fig.3.6. Pengabungan Materials and Components

F. Changing Icon Project With Micro Program Anggelo

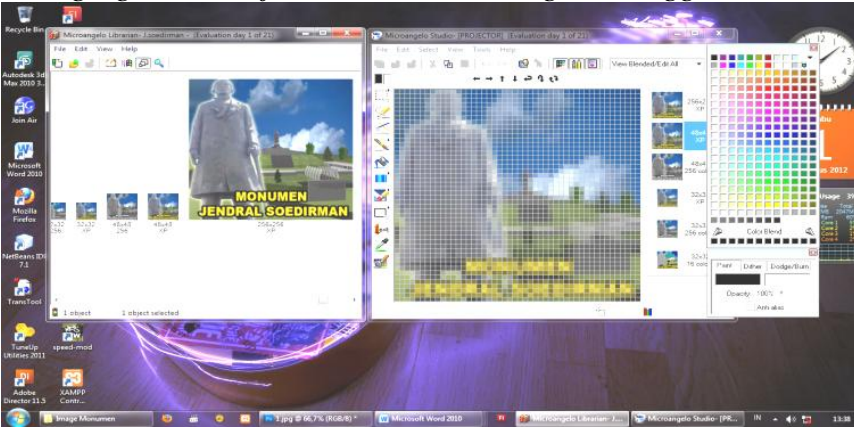

Fig.3.7. Changing Icon Project
IV. THE BURNING COVER HOME

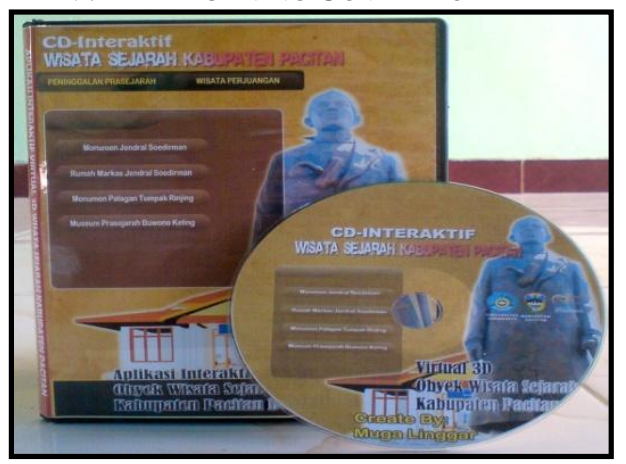

Fig.4.1. front cover

\section{A. The Burning Rear Cover}

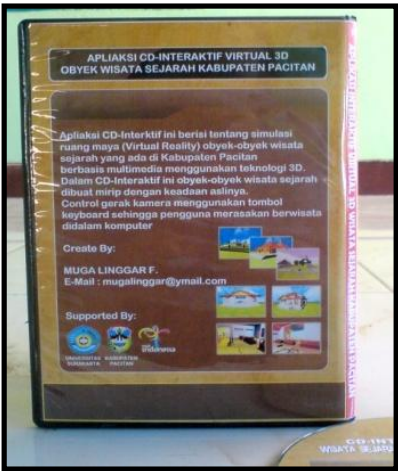

Fig. 4.2. Rear cover

B. Main Menu Display

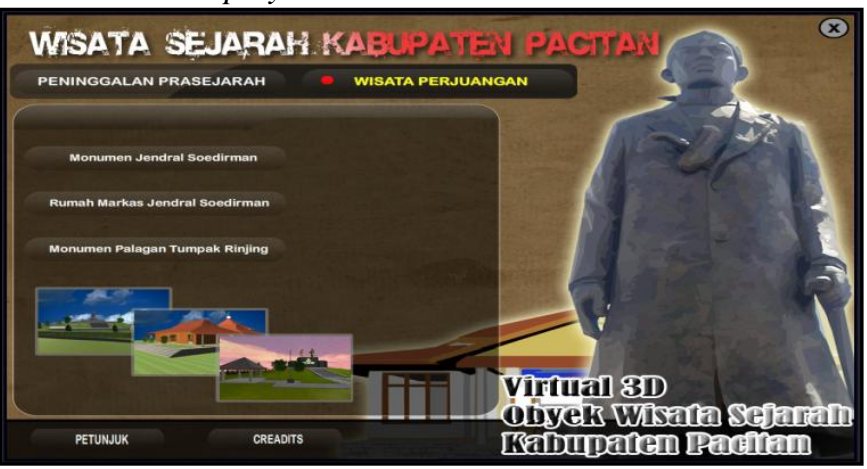

Fig.4.3. Main menu

C. Virtual Reality Display General Sudirman Monument

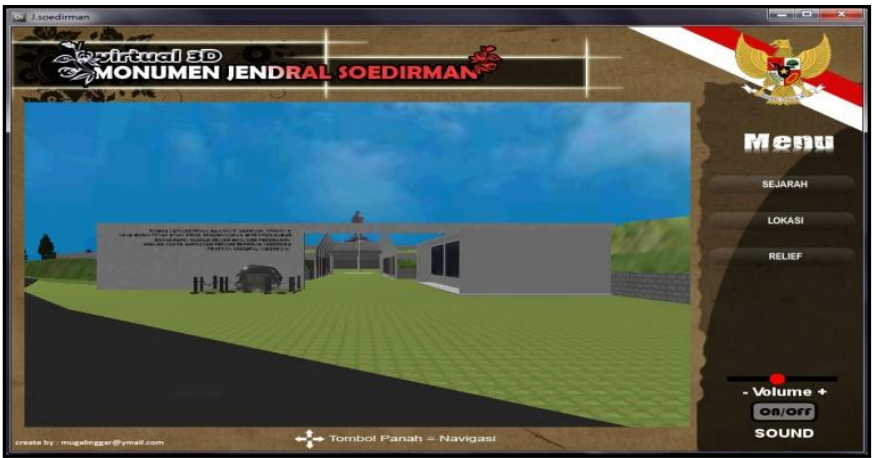

Fig.4.4. Virtual Reality Monument General Sudirman 
D. Monuments History Display General Sudirman

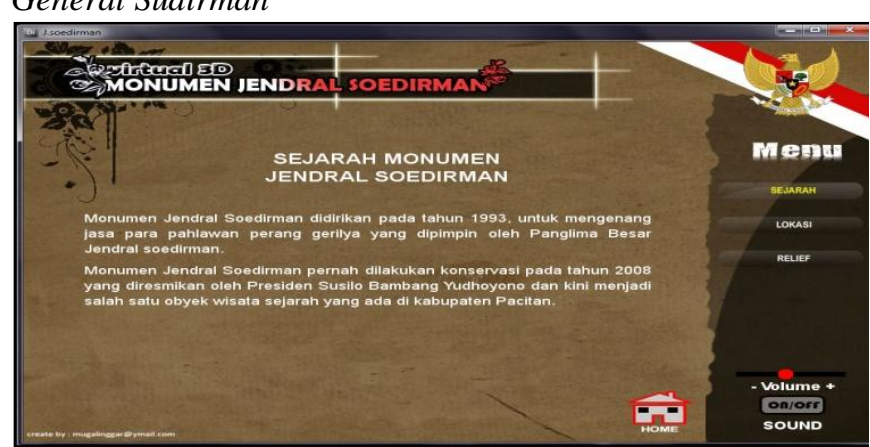

Fig.

4.5. Historical

Monument

General

Sudirman

E. Display Location Monument Jen Sudirman

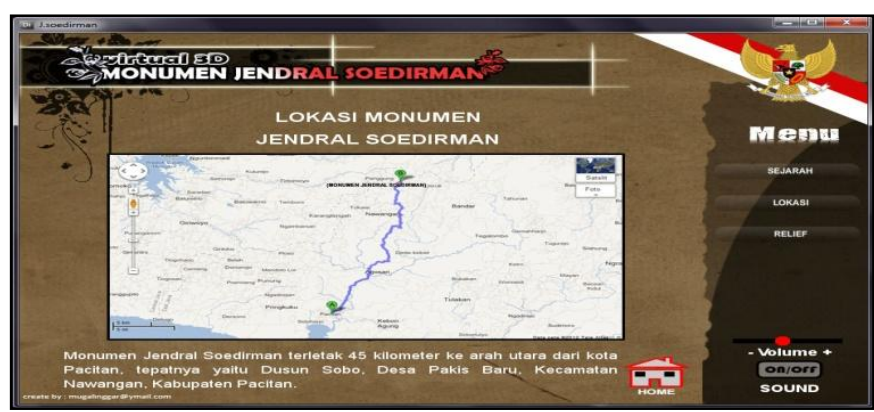

Fig.4.6. Location Monument General

F. Display Monument Relief General Sudirman

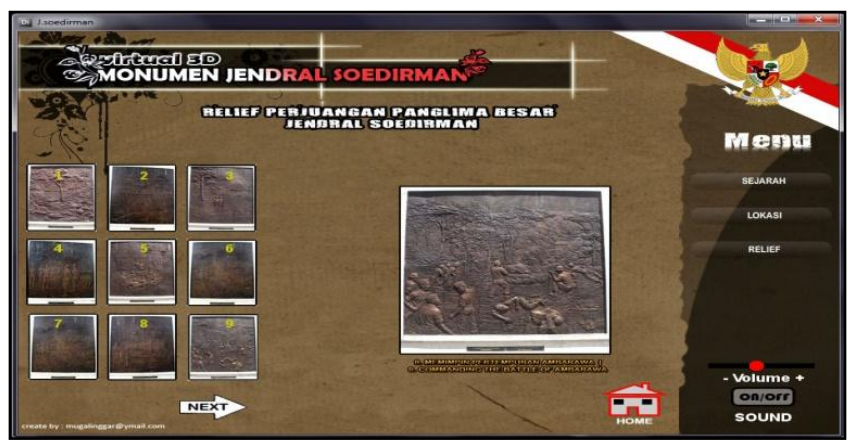

Fig. 4.7. Location Monument General

\section{CONCLUSION}

a) The creation of digital media information in the form Application Object Interactive 3D Virtual Tour History-Based Multimedia Pacitan difamami simple concept, easy to operate, attractive, clear and useful. b) This application can provide knowledge about the history of the monument Pacitan General Sudirman, Tumpak Rinjing Theater Monument and Museum lane Keling.

c) This application can be used as a medium of information and the promotion of historical Pacitan to students and the public.

\section{REFFERENCE}

[1] Ariyus, Doni, Keamanan Multimedia,Penerbit Andi, 2009.

[2] Bawonosari, Lintang Yuniar, Journal,Pembuatan Museum Virtual Budaya Dan Sejarah, Universitas Gunadarma 2011.

[3] Dr. Erhans A., CorelDraw X4, PT Ercontra Rajawali, Cirebon 2005

[4] Hendratman, Hendi, The Magic Of Macromedia Director, Informatika. Bandung 2008.

[5] Hendratman, Hendi, The Magic Of 3D Studio Max, Informatika. Bandung 2011.http://pacitantourism.com diakses pada tanggal 20 mei 2012

[6] Hari Aria Soma, Animasi Kreatif Fundamental, Elex Media Komputindo. Jakarta 2007.

[7] Ir. Suryanto Thabani, Macromedia Director 8.5 Presentasi Multimedia Interaktif, Salemba. Jakarta 2008.

[8] Kartikadarma, Etika, Rancang Bangun Aplikasi E-Museum Sebagai Upaya Melestarikan Kebudayaan, Upn Veteran Yogyakarta 2011.

[9] Madcoms, Students Book Series Adobe Photoshop CS4, Yogyakarta 2009.

[10] Mulyanta, Leong Marlon, Media Pembelajaran, Universitas Atmajaya. Yogyakarta .2009

[11] Novitasari, Naskah Publikasi, Virtual Gallery Museum Gunung Merapi Sleman. Yogyakarta 2011.

[12] Riyadi Gondang, Susanta Heri, Journal, Model Kota 3 Dimensi Kawasan Simpang Lima Untuk Eksplorasi Kota Secara Virtual, Media Teknik 2008

[13] Sartono, Qomaruddin, Babad Tanah Pacitan Dan Perkembanganya, Pustaka Pacitan 2006.

[14] Setyawan Agung, Bagus Rendra, Naskah Publikasi, Perancangan Virtual Reality Sebagai Media Promosi Pada PT.Aryaguna Putra.Yogyakarta 2011.

[15] Sugianto, Mikael, Bedroom Interior Design With 3D Studio Max9, Elex Media Komputindo. Jakarta 2008.

[16] Supriadi, Yuniar, Adobe Photoshop CS3 Untuk Segala Tingkat, Elex Media Komputindo. Jakarta 2009.

[17] Susila, Candra Budi, Laporan Kerja Praktik, Media Pembelajaran Interaktif Pengenalan Huruf Hijaiyah Pada Taman Kanak-Kanak (TK) Pertiwi Kecamatan Pacitan, Surakarta 2011.

[18] Syamsudin, Deddy, Tutorial 3D max CHIP CD Indonesia. 2005-2006.

[19] Undang-Undang Republik Indonesia, No.9 Tahun 1990, Jakarta 18 Oktober 1990

[20] Vaughan, Tay, Multimedia Making It Work Edisi 6, Penerbit Andi. Yogyakarta 2006.

[21] Wiradinata, Gilang, Desain Interior Dengan 3Ds Max 2009, Penerbit Andi. Yogyakarta 2009.

[22] Gerbang Emas, Bangun Monumen Jejak Panglima Besar, Pacitan 2008 